\title{
Disseksjoner på halsen - valg av bildediagnostikk
}

En arteriedisseksjon oppstår som følge av en rift i karveggens intimalag hvor blod strømmer inn i et falskt lumen og danner et intramuralt hematom. Veggen mellom det ekte og det falske lumenet kalles gjerne en «intimaklaff» (flap). Dersom hematomet sitter mellom intima og media vil det bule innover i lumen og gi en stenose og ofte en fortykkelse av arterieveggen. Dersom hematomet sitter mellom media og adventia, vil det føre til et pseudoaneurisme (1). Komplikasjoner inkluderer cerebral iskemi som følge av enten embolusdanning ved riften i intima eller hypoperfusjon på grunn av en signifikant stenose. En sjelden gang kan riften gå gjennom adventitia og gi subaraknoidalblødning dersom disseksjonen strekker seg intrakranialt. Ulike radiologiske undersøkelser kan påvise ulike komponenter av disseksjonen.

MR-undersøkelse med anatomiske snittbilder er best egnet til å påvise vegghematomet som er karakteristisk for en arteriedisseksjon (2). I Amthor og medarbeideres kasuistikk ser man det karakteristiske «halvmånetegnet» i veggen på a. carotis interna bilateralt (3). Man kan supplere med MR-angiografi for fremstilling av den intraluminale stenosen samt diffusjonsvektede bilder gjennom hjernen for å påvise iskemi. MR-undersøkelsen kan gjøres uten kontrast og uten strålebelastning, men innebærer større snittykkelse enn ved CT-undersøkelse, er mindre tilgjengelig, og innoperert metall kan være en kontraindikasjon.

CT-angiografi med intravenøs kontrast fremstiller konturen av arterielumen og dermed stenoser og pseudoaneurismer godt. Det klassiske funnet ved disseksjon er en langstrakt eksentrisk avsmalning av kontrasten, og noen ganger kan man se «intimaklaffen» (2). Man kan også få inntrykk av vegghematomet, men det er vanskeligere å påvise enn ved MR-undersøkelse. CT-angiografi har høyere oppløsning og er lettere tilgjengelig enn MR-undersøkelse, men er strålebelastende og krever intravenøs kontrast. Det siste kan være kontraindisert ved nyresvikt og allergi.

Ultralydundersøkelse av halsarteriene kan påvise «intimaklaffen», det falske lumenet og hematomet $i$ arterieveggen, mens man ved hjelp av dopplerultralyd kan påvise hemodynamiske endringer som følge av stenosen $(4,5)$. En ultralydundersøkelse er ikke-invasiv og lettere tilgjengelig enn en MR-undersøkelse. Den er imidlertid brukeravhengig, og man får ikke undersøkt distale del av a. carotis interna fordi benete strukturer hindrer innsyn. Det samme gjelder for vertebralisarteriene. Således kan man bruke ultralyd til å påvise en disseksjon i proksimale del av a. carotis interna, men ikke i de øvrige halsarteriene (6).

Historisk er konvensjonell kateterbasert angiografi gullstandarden for disseksjoner. Man så en langstrakt avsmalning av kontrasten, men selve vegghematomet var det ikke mulig å påvise (2). Nå brukes denne metoden svært sjelden diagnostisk, da den krever intervensjon og er strålebelastende.

I en systematisk oversiktsartikkel fra 2009 sammenlignet man CTangiografi med MR/MR-angiografi, og fant dem likeverdige for påvisning av disseksjon i a. carotis og a. vertebralis (7). I en annen artikkel fra 2008 vurderte to nevroradiologer CT-angiografi og MR/MR-angiografi av de samme 18 pasientene med disseksjoner.
De foretrakk CT-angiografi for disseksjoner i vertebralisarteriene, mens metodene var jevngode for vurdering av carotisarteriene (8). En ultralydundersøkelse må suppleres med ytterligere bildediagnostikk hvis den er negativ $(6,9)$. Hos pasienter med Horners syndrom som eneste tegn på carotisdisseksjon kunne for eksempel ultralydundersøkelse ikke påvise tilstanden hos tre av ti med senere bekreftet disseksjon (10).

Flere internasjonale faggrupper, som American Heart Association, American Stroke Assosciation og International Headace Society, kommer ikke med konkrete anbefalinger utover å påpeke at alle de tre metodene kan brukes, men at man noen ganger må kombinere dem for å kunne stille endelig diagnose $(11,12)$. I flere oversiktsartikler anbefales det å starte med MR/MR-angiografi, som er best egnet til å påvise det intramurale hematomet og cerebral iskemi $(3,6,9,13)$.

\section{Erik Magnus Berntsen}

erik.berntsen@stolav.no

Erik Magnus Berntsen (f. 1982) er ph.d., førsteamanuensis II, spesialist i radiologi med europeisk diplom i nevroradiologi (EDiNR) og medlem av Tidsskriftets redaksjonskomité

Forfatter har fylt ut ICMJE-skjemaet og oppgir ingen interessekonflikter.

\section{Litteratur}

1. Caplan LR. Dissections of brain-supplying arteries. Nat Clin Pract Neurol 2008, 4: $34-42$.

2. Rodallec MH, Marteau V, Gerber S et al. Craniocervical arterial dissection: spectrum of imaging findings and differential diagnosis. Radiographics 2008; 28: $1711-28$.

3. Amthor KF. Haslund A. Bilateral carotisdisseksjon. Tidsskr Nor Legeforen 2017; 137: 203.

4. Solbakken T, Kabalaoui S, Lye S. Ultralydfunn ved carotisdisseksjon. Tidsskr Nor Legeforen 2017: 137: 204

5. Ortiz J, Ruland S. Cervicocerebral artery dissection. Curr Opin Cardiol 2015; 30: $603-10$

6. Debette S, Leys D. Cervical-artery dissections: predisposing factors, diagnosis, and outcome. Lancet Neurol 2009; 8: 668-78.

7. Provenzale JM, Sarikaya B. Comparison of test performance characteristics of MRI, MR angiography, and CT angiography in the diagnosis of carotid and vertebral artery dissection: a review of the medical literature. AJR Am J Roentgenol 2009: 193: 1167-74

8. Vertinsky AT, Schwartz NE, Fischbein NJ et al. Comparison of multidetector CT angiography and MR imaging of cervical artery dissection. AJNR Am J Neuroradiol 2008; 29: 1753-60.

9. Robertson JJ, Koyfman A. Cervical Artery Dissections: A Review. J Emerg Med 2016: 51: 508-18.

10. Arnold M, Baumgartner RW, Stapf $C$ et al Ultrasound diagnosis of spontaneous carotid dissection with isolated Horner syndrome. Stroke 2008; 39: 82-6.

11. Brott TG, Halperin JL, Abbara $S$ et al. 2011 ASA/ACCF/AHA/AANN/AANS/ACR/ ASNR/CNS/SAIP/SCAI/SIR/SNIS/SVM/SVS guideline on the management of patients with extracranial carotid and vertebral artery disease. Circulation 2011; 124: e54-130.

12. Headache Classification Committee of the International Headache S. The International Classification of Headache Disorders. 3rd edition (beta version). CephaLalgia 2013; 33: 629-808

13. Ben Hassen W. Machet A, Edjlali-Goujon M et al. Imaging of cervical artery dissection. Diagn Interv Imaging 2014; 95: 1151-61. 